\title{
Nabokov's scientific artistry
}

\section{Vladimir Lukhtanov delights in a treatise on the luminary's contribution to biology.}

$\mathrm{V}$ ladimir Nabokov's influence on Russian and English literature and language is assured. Many people also know of the novelist's lifelong passion for butterflies. But his notable contributions to the science of lepidopterology and to general biology are only beginning to be widely known.

Nabokov was no amateur entomologist. He served for six years as curator of the butterfly collection at Harvard University's Museum of Comparative Zoology in Cambridge, Massachusetts, and published a dozen papers on taxonomy - the description and classification of organisms - that remain important. His observations on butterfly morphology have stimulated breakthrough research in evolutionary biology. Several of his original biogeographic hypotheses have been confirmed in the past few years. Fine Lines, a collection edited by Stephen Blackwell and Kurt Johnson, explains the importance of Nabokov's scientific work and traces its influence on his novels.

The book begins with 154 of Nabokov's black-and-white and colour drawings of butterflies' fine anatomical structures. Most represent the European, Asian and American species of the 'blues' of the tribe Polyommatini, Nabokov's favourite group. Ten essays follow, by prominent researchers including evolutionary biologist James Mallet, current Harvard butterfly curator Naomi Pierce and lepidopterist Robert Pyle, explaining the interplay of science and art in Nabokov's writings. Fine Lines clearly demonstrates the significant impact that science had on Nabokov's evolution as a writer.

The decision to open the book with the drawings is a masterstroke. They illustrate one of the most important aspects of Nabokov's creativity - his tremendous attention to details, described with scrupulous precision. In his novels, he seamlessly marshals minutiae - impressions, passing fancies, ideas - to create a universe strongly rooted in observation. The particular or apparently trivial was, for him, always worth probing. In his entomological studies, he analysed fine, nearly invisible, dots on the wings of New and Old World butterflies to hint at what may have happened on Earth millions of years ago. With no palaeontological data, Nabokov speculated that North and then South America were populated by five waves of butterflies migrating from Asia (V. Nabokov Psyche 52, $1-61 ; 1945)$ - a picture confirmed by DNA analysis almost 70 years on (R. Vila et al. Proc. R. Soc. B 278, 2737-2744; 2011).

This pointillism is harder than it seems. Piling up millions of elements can easily end in chaos; to create a picture, one needs to understand the nature of these elements and to be able to choose between them. The core of scientific drawing differs greatly from photography in focusing on the heart of the matter and avoiding unnecessary details. This is important for science, and no less for art. Both have the same central goal - to reveal an unknown or invisible essence of things. That is one of the main points of Fine Lines.

Yet science and art diverge in their communication. In science, the ability to convey the idea properly and simply is a matter of special talent, but almost everyone can learn to do it. Not so in art. Nabokov's drawings are scientifically perfect, but also staggeringly fine aesthetically. They show how the merging of content and form in art conveys ideas wonderfully. However, even the most wonderful idea becomes banal if artistry is lacking.

The personal, artistic and scientific aspects of Nabokov's life were tightly intertwined. As one of the book's essayists, science writer Dorion Sagan, concludes, nature and art were a continuum for him:

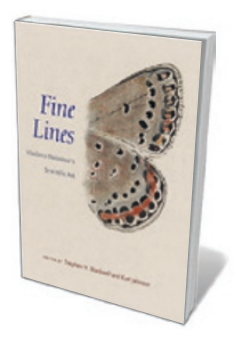

Fine lines: Vladimir

Nabokov's Scientific Art EDITED BY STEPHEN H. BLACKWELL AND KURT JOHNSON Yale University Press: 2016. "the distinct but equally necessary paths of art and science seem to scale opposite sides of the same majestic mountainscape".

Nabokov's fiction is permeated by science, as Fine Lines amply reveals. He was a master in the use of motif and symbols. In his novel Lolita (Olympia, 1955), for instance, the town Lepingville is named after 'lepping', butterfly hunters' slang for chasing butterflies, and Elphinstone after Elphinstonia, a subgenus in the white butterfly genus Euchloe. The fictional play-within-the-novel, The Enchanted Hunters, is built almost entirely on symbols associated with butterflies. Diana, its protagonist, is both the virgin goddess of hunting and a butterfly species (Speyeria diana). In his essay, Nabokov scholar Brian Boyd reveals that Edusa Gold, who directs the play, is an echo of Colias edusa, an old but preocccupied name for the clouded yellow (now Colias croceus). I can add that her sister Electra Gold was named after Colias electra, an unavailable name for the African clouded yellow, now Colias electo. That these names are effectively hidden - no longer in use, but buried in lists of unavailable scientific epithets - chimes with the secrecy in this controversial novel.

I prepared this review at the Nabokov House Museum in St Petersburg, Russia. While there, I discovered in the Nabokov family's copy of An Illustrated Natural History of British Butterflies and Moths by Edward Newman (William Glaisher, 1870) that Nabokov had, as a child, coloured in the black-and-white image of the clouded yellow with remarkable accuracy. As zoologist Victor Fet describes in Fine Lines, Nabokov's childhood concentration on butterfly collecting and drawing effectively provided very specific training in memory and paying attention, as well as that focus on minute detail.

Few have so beautifully and meaningfully meshed serious scientific endeavour with artistic brilliance, visual and verbal. Fine Lines helps us to understand the phenomenon of creativity, without which neither good science nor true art can exist.

Vladimir Lukhtanov is leading research scientist at the Zoological Institute of the Russian Academy of Sciences in St Petersburg, and professor of entomology at Saint Petersburg State University. e-mail:lukhtanov@mail.ru 